\title{
PRODUCT TESTING STRATEGY IMPLEMENTATION RESULTS BIOTECHNOLOGY FEED: PAPER
}

\author{
LAODE MUH MUNADI \\ Postgraduate Agricultural Sciences Halu Oleo University, \\ Kemaraya, Kendari, Southeast Sulawesi \\ Email: lmmunadi@gmail.com
}

\section{INTRODUCTION}

Since long ago the science of biotechnology has developed in Indonesia, but tends to be slow due to several factors. The first factor is research funding in biotechnology. Biotechnology research is needed to improve the quantity and quality of products as well as knowledge of biotechnology. Another factor is the low human resources, facilities and government policies that seem to prolong the marketing process of genetically engineered products. Biotechnology for the world has a positive role, especially agriculture, health and the environment. Biotechnology in agriculture, helping to reduce the food crisis, improve food quality and increase the amount of agricultural production. The application of biotechnology in Indonesia has developed for a long time, for example the manufacture of cheese, tempeh, oncom and so on. But modern biotechnology only developed in 1985 when biotechnology such as agricultural biotechnology IPB, health biotechnology in UGM and Industrial Biotechnology in ITB Bandung.

Natural Resources (SDA) is a natural wealth that can continue to exist as long as its use is not overextended. Plants, animals, microorganisms, sunlight, wind, and water are abundant in nature. Its use must remain limited and maintained in order to continue to be sustainable. Biotechnology is a science about the utilization of living things (bacteria, functions, and viruses) as well as products of living things (enzymes, alcohol) in the production process to produce goods and services. The development of biotechnology is not only in biology alone, but also in other applied and pure sciences, such as biochemistry, computers, molecular biology, microbiology, genetics, chemistry, mathematics, and so on. Biotechnology is a science that utilizes living things (microorganisms, animals and plants) or parts of living beings to make products or simplify the process.

Increasing nutrition improvement in food-prone communities, poor household access to food, increased rice self-sufficiency, maintaining food prices for lower middle class communities, maintaining farmers' exchange rates, and increasing commodity bargaining power, comparative advantage of the agricultural sector is a noble goal that must be realized by the government towards a prosperous society. The tendency to increase animal protein needs is positively correlated with an increase in the number of livestock production needs. Thus, it stimulates the increase of livestock population, which certainly increases the need for feed. Looking at the role of livestock subsectors in the economy so that the development of livestock subsectors becomes an alternative option for the government and the community. 
Acceleration of livestock development will also provide animal food or increase the supply of livestock products while creating income for indonesian.

The development of farms in terms of the application of feed biotechnology paradigm long in the development of farms and until now runs sluggish and unattractive in its development. So this paper aims to review previous research on the application of feed biotechnology and its testing strategy in livestock. Because, in fact a livestock to be able to produce and reproduce well must get good quality feed support and most importantly to support the success of livestock development is the availability of feed sources, both sourced from follow-up and forage.

\section{DATA COLLECTION METHODS}

Data collection method in the preparation of papers in the form of library research, which is directly related to the application of feed biotechnology in support of the provision of quality feed sources in Indonesia. Thus, the study in this paper uses a library research approach, namely in presenting and verifying and concluding data, not using calculations. All literature, collected directly relevant to the case. The literature that has been obtained is arranged in such a way that it reflects its pattern as a case. This library research is intended to reveal various theories relevant to the problem being studied. This technique is done by reading, studying and studying literature related to the application of feed biotechnology and its testing strategy in livestock.

\section{DISCUSSION}

\section{Feed Ingredients}

Feed material is a material produced by agriculture, fisheries, farms, or other materials, and worth using as feed, both processed and unprocessed. Feed plays an important role in the cultivation, especially ruminant livestock in particular, such as cows, goats, sheep, and buffalo. Feed affects 60-70\% of livestock productivity (Muhtarudin et al. 2018). This greatly affects the profits of farmers in the livestock business. The price of feed is expensive, while livestock productivity is low or fixed, then the profit earned becomes small or even loss (Siahaan and Rusiadi 2018). Ruminant animal feed is mostly derived from plants or forage feed as a source of fiber. Forage feed is absolutely necessary ruminant livestock, because ruminants have rumen containing fiber-digesting microbes (Tohiran et al. 2019). Rumen microbes as a source of amino acids of ruminants to meet livestock needs by $60-80 \%$ (Tohiran et al. 2017).

\section{Forage Feed Ingredients and Food Crop Follow-up Results}

Animal feed in the form of reinforcing feed (concentrates) produced with various raw materials of grass, hay and agricultural follow-up waste mixed with sugar cane drops or mollasse, EM4, bran and so on. Fulfillment of local feed needs as the increasing business of livestock. The fundamental change in feed is seen after Indonesia was hit by the economic crisis, by developing farms as a local resource base in livestock development (Nugroho et al. 2016). Grass production field is a type of grass mixed and grown in the field, such as 
paspalum, axonopus, cynonon polytrias, and some types of digitaria. This grass generally grows on marginal land, plantations and forests with relatively low quality characterized by its protein content of $8-10 \%$ and TDN content ranging from $65-70 \%$. The quality of grass field in Indonesia is relatively lower compared to that grown in subtropical areas. This is due to greater evaporation, so the content of coarse fibers increases. More details of the application of biotechnology feed on grass field presented in Table 1.

Table 1. Application of Biotechnology Feed On Grass Field

\begin{tabular}{|l|l|l|}
\hline Research & \multicolumn{1}{|c|}{$\begin{array}{c}\text { Regency } \\
\text { /City }\end{array}$} & \multicolumn{1}{c|}{ Nutritional Content } \\
\hline Nitis et al. (1998) & Bali & PK 8,77\%, SK 27,88\%, BK 43,88\% \\
\hline Herman (1989) & Riau & $\begin{array}{l}\text { BK 78,37\%, PK 7,12\%, SK 27,59\%, LK 0,91\%, BETN } \\
35,61 \% \text { dan TDN 54,29\% }\end{array}$ \\
\hline Fathul et al. (2003) & Lampung & $\begin{array}{l}\text { BK 35,40\%, PK 6,70\%, LK 1,80\%, SK 34,20\%, Abu } \\
9,70 \%, \text { BETN 47,60\%, TDN 56,20\%, Ca 0,36\%, dan P } \\
0,23 \% .\end{array}$ \\
\hline Rukmana (2005) & Yogyakarta & $\begin{array}{l}21,60 \% \text { BK, 10,20\% Protein, 52\% Energi, Kalsium 0,37\%, } \\
\text { Fosfor 0,23\%, dan 76\% Air }\end{array}$ \\
\hline Sriyana (2005) & Bogor & LK 1,712-1,763\% \\
\hline Yoku (2013) & Papua Barat & Abu 5,27\%-10,57\% dan LK 1,98\%-2,81\%. \\
\hline Manu (2013) & Manado & $\begin{array}{l}\text { Abu Musim Hujan 9,81-11,5\%, Awal Kemarau 10,21- } \\
11,39 \% \text { dan akhir kemarau 12,17-19,92\% }\end{array}$ \\
\hline Infitria dan Khalil, & Padang & Bahan Kering 6,6\% - 10.0 \% \\
(2014) & Semarang & SK 29,03\%, PK 6,99\%, dan TDN 46,6\%. \\
\hline Umar (2015) & Malang & $\begin{array}{l}\text { BK 2,41\%, LK 2,59\%, BETN 36,7\%, TDN 46,7\% dan Abu } \\
21,0 \% .\end{array}$ \\
\hline Aprilia (2015) & Purwokerto & $\begin{array}{l}\text { BK 24.68\%, ABU 14.26\%, PK 8.90\%, SK 33.31\%, LK } \\
1.75 \% \text { dan BETN 41.76\%. }\end{array}$ \\
\hline Bahrun et al. (2018) & $\begin{array}{l}\text { BK 1,29\%, BO 1,58\%, LK 0,90\%, NDF 0,74\% dan ADF } \\
0,68 \% . ~\end{array}$ \\
\hline Eko Jatmiko (2019) & Jakarta &
\end{tabular}

Forage ruminant fodder at the time of testing is expected to have an impact to increase the production of ruminants. But it must also be followed by an increase in the provision of forage that is quite good in quantity and quality (Lukiwati et al. 2016). Several factors that hinder the provision of forage, namely the change in the function of land as a source of growth of feed forage into residential land, food crop land, and industry (Mayulu and Suhardi 2016). Measures to reduce the limitations of feed forage utilizing agricultural follow-up products (Haryo et al. 2017). So, to see the quality of agricultural crop follow-up results, the application of biotechnology aims to find the origin of agricultural waste that can be used as a source of ruminant animal feed. Biotechnology test results of agricultural crop follow-up products presented in Table 2.

Table 2. Application of Feed Biotechnology in Agricultural Follow-up Results

\begin{tabular}{|c|l|l|l|}
\hline Research & \multicolumn{1}{|c|}{ Waste } & \multicolumn{1}{c|}{ Research Results } & \multicolumn{1}{c|}{ Deficiency } \\
\hline & & BK 81,24\%, PK 4.05\%, SK & Coarse fibers of \\
straw contain silica \\
Utomo (2001) & Rice Straw + Rumen & $\begin{array}{l}\text { 35,06\%, BO 78,07\%, } \\
\text { Kalsium 0,20\%, Fosfor }\end{array}$ & $\begin{array}{l}\text { as much as 12-16\% } \\
\text { of dry material } \\
\text { (Insoluble in rumen }\end{array}$ \\
\hline
\end{tabular}




\begin{tabular}{|c|c|c|c|}
\hline & & & liquid) \\
\hline $\begin{array}{l}\text { Hanum dan } \\
\text { Usman }(2011)\end{array}$ & Rice Straw (Bali) & $\begin{array}{l}\text { BK } 79,75 \%, \text { PK } 4,90 \%, \text { LK } \\
1,56 \% \text {, SK } 27,80 \text { dan Abu } \\
12,32\end{array}$ & $\begin{array}{l}\text { Utilization ranges } \\
\text { from } 31-39 \% \text { in } \\
\text { Indonesia } \\
\text { (Fertilizer } 36 \% \text { and } \\
\text { burn } 62 \% \text { ) }\end{array}$ \\
\hline $\begin{array}{l}\text { Syapura dan } \\
\text { Pratama (2013) }\end{array}$ & $\begin{array}{l}\text { Straw Rice } \\
\text { Ammoniation }+ \\
\text { Konsetrat (Buffalo) }\end{array}$ & $\begin{array}{l}\text { The total VFA produced } \\
\text { ranges from } 16.9-20.9 \%\end{array}$ & $\begin{array}{l}\text { Low digestibility of } \\
\text { microbes with } \\
\text { buffalo stool } \\
\text { inoculum, thought } \\
\text { to be due to the } \\
\text { changing } \\
\text { population of } \\
\text { microorganisms } \\
\text { contained in the } \\
\text { stool liquid } \\
\text { compared to rumen } \\
\text { liquid. }\end{array}$ \\
\hline $\begin{array}{l}\text { Saputro et al. } \\
\text { (2015) }\end{array}$ & $\begin{array}{l}\text { Straw Rice }+ \\
\text { Aspergillus niger }+ \\
\text { Lactobacillus } \\
\text { plantarum }\end{array}$ & $\begin{array}{l}\text { Straw Rice+ Aspergillus } \\
\text { niger digestitude dry } \\
\text { ingredients }(\mathrm{KcBK}) \text { treatment } \\
\text { of } 0 \%, 5 \%, 10 \% \text {, and } 15 \% \text { of } \\
\text { Aspergillus niger levels } \\
\text { within } 48 \text { hours }(20,26 \pm 3,01 \text {; } \\
25,95 \pm 5,00 ; 27,00 \pm 9,85 ; \text { dan } \\
24,59 \pm 0,76 \%) \text { dan waktu } 72 \\
\text { jam }(31,00 \pm 2,62 ; 35,04 \pm 2,32 \text {; } \\
37,12 \pm 1,34 ; \text { dan } \\
35,77 \pm 2,41 \%) \\
\text { Straw Rice }+ \text { Lactobacillus } \\
\text { plantarum digestient organic } \\
\text { matter (KCBO) with } \\
\text { treatment of } 0,5,10 \text {, and } \\
15 \% \text { of Aspergillus niger } \\
\text { level within } 48 \text { hours } \\
(36,63 \pm 1,63 ; 36,99 \pm 2,72 ; \\
39,32 \pm 1,13 ; \text { and } \\
38,86 \pm 0,94 \%) \text { and time } 72 \\
\text { hours }(44,07 \pm 2,62 ; \\
42,13 \pm 6,05 ; 45,65 \pm 2,52 ; \text { and } \\
46,30 \pm 0,65 \%) \text {. }\end{array}$ & $\begin{array}{l}\text { The use of } \\
\text { molasses substrates } \\
\text { is better when } \\
\text { compared to bran, } \\
\text { this is seen from } \\
\text { the analysis of PK, } \\
\text { SK, LK, ADF, and } \\
\text { physical test results } \\
\text { of fermented rice } \\
\text { straw. } \\
\text { The best use of } \\
\text { Aspergillus niger } \\
\text { and Lactobacillus } \\
\text { plantarum for rice } \\
\text { straw fermentation } \\
\text { is } 15 \% \text { Aspergillus } \\
\text { niger and 10\% } \\
\text { Lactobacillus } \\
\text { plantarum from dry } \\
\text { material }\end{array}$ \\
\hline Iqbal et al. (2016) & Straw Rice +EM4 & $\begin{array}{l}\text { J0 (control or without EM-4), } \\
\text { J1 (2\% EM-4), J2 (3\% EM- } \\
\text { 4), J3 (4\% EM-4). BK } \\
(92,46 \%, 91,30 \%, 90,46 \% \\
90,05 \%) \text { PK }(7,15 \%, 6,75 \% \\
7,05 \%, 6,77 \%), \text { SK }(28,38 \%, \\
30,79 \%, 29,44 \%\end{array}$ & $\begin{array}{l}\text { Em-4 usage rate up } \\
\text { to } 4 \% \text { has not been } \\
\text { able to improve the } \\
\text { quality of rice } \\
\text { straw }\end{array}$ \\
\hline Setiarto (2016) & Straw Rice +Mikroba & $\begin{array}{l}\text { Microbial fermentation } \\
\text { Trichoderma sp., Trametes } \\
\text { sp., and Aspergillus sp. has a } \\
\text { quality ratio C/N }(18,88), \\
\text { kadar C }(35,11 \%), \text { kadar } \mathrm{N} \\
(1,86 \%), \text { kadar } \mathrm{P}_{2} \mathrm{O}_{5}(0,21 \%) \text {, }\end{array}$ & $\begin{array}{l}\text { Bioconversion of } \\
\text { rice straw into } \\
\text { biogas has better } \\
\text { economic prospects } \\
\text { to be applied on a } \\
\text { medium and large }\end{array}$ \\
\hline
\end{tabular}




\begin{tabular}{|c|c|c|c|}
\hline & & $\begin{array}{l}\text { kadar } \mathrm{K}_{2} \mathrm{O}(5,35 \%) \text {, kadar air } \\
(55 \%) \text {, Kalsium (Ca) } 4,2 \% \text {, } \\
\text { serta unsur mineral mikro } \\
\text { seperti Magnesium }(0.5 \%) \text {, } \\
\mathrm{Cu}(20 \mathrm{ppm}), \mathrm{Mn}(684 \mathrm{ppm}) \\
\text { dan } \mathrm{Zn}(144 \mathrm{ppm}) \text {. } \\
\text { Rice straw silage } \\
\text { Lactobacillus bulgaricus, } \\
\text { Lactobacillus plantarum, and } \\
\text { Pledioccus pentosomonas } \\
\text { yellowish green color, pH } \\
4,2 \text {; lactic acid } 1.5-2.5 \% \text {, } \\
\text { butyric acid } 0.1 \% \text {, acetic acid } \\
\text { O.5-0.8\%; and N-NH3 } 5-8 \% \text {. } \\
\text { Fermented rice straw } \\
\text { Methanobacterium and } \\
\text { Methanobacillus metanogenic } \\
\text { bacteria are very high quality } \\
\text { because it has a calorific } \\
\text { value of } 590 \text { - } 700 \text { kcal per } \\
\text { cubic equivalent to } 0.5 \mathrm{~kg} \text { of } \\
\text { liquid petroleum gases, } 0.5 \\
\text { liters of gasoline and } 0.5 \text { liters } \\
\text { of diesel oil. }\end{array}$ & $\begin{array}{l}\text { scale when } \\
\text { compared to } \\
\text { compost and silage } \\
\text { bioconversion. }\end{array}$ \\
\hline $\begin{array}{l}\text { Ilham et al. } \\
\text { (2018) }\end{array}$ & $\begin{array}{l}\text { Rice Straw+ Ureat } \\
\text { Molasses+ } \\
\text { Microorganism } \\
\text { Effective-11 (MA-11) }\end{array}$ & $\begin{array}{l}\text { The physical quality of rice } \\
\text { straw diamoniated is light } \\
\text { brown/brownish color, } \\
\text { ammonia smell, smooth } \\
\text { texture, Ph 7.8, Temperature } \\
43.660 C \text {. Proximate analysis } \\
\text { obtained moisture content of } \\
8.09 \% \text {, protein 5.65\%, fat } \\
1.99 \% \text {, coarse fiber } 33.60 \% \text {, } \\
\text { BETN } 31.66 \% \text {, and ash } 27 \% \text {. }\end{array}$ & $\begin{array}{l}\text { If you do not add } \\
\text { urea to rice straw } \\
\text { will not increase } \\
\text { the quality of } \\
\text { ammonia rice straw }\end{array}$ \\
\hline Research & Waste & Research Results & Deficiency \\
\hline $\begin{array}{l}\text { Kusumaningrum, } \\
\text { and Aditiawati } \\
(2018)\end{array}$ & $\begin{array}{l}\text { Corn Straw+cow } \\
\text { rumen liquid }\end{array}$ & $\begin{array}{l}\text { Numerically, the } \mathrm{pH} \text { range of } \\
\text { treatment is } 6.89-7.05 ; \mathrm{VFA} \\
\text { concentration of } 107-110 \\
\mathrm{mM} \text {, ammonia concentration } \\
\text { of } 23.92-29.88 \mathrm{mg} / 100 \mathrm{ml} \text {, } \\
\text { total gas production of } 27.47 \\
-46.31 \mathrm{ml} / 200 \mathrm{mg} \text { and } \\
\text { microbial biomass production } \\
\text { of } 40.60-56.80 \mathrm{mg} / 20 \mathrm{ml} \text {. }\end{array}$ & $\begin{array}{l}\text { Treatment carried } \\
\text { out for } 24 \text { Hours }\end{array}$ \\
\hline $\begin{array}{l}\text { Mardalena, and } \\
\text { Ediyanto (2018) }\end{array}$ & $\begin{array}{l}\text { Corn Straw +Prolinas } \\
\text { (PSFP) }\end{array}$ & $\begin{array}{l}\text { KBK and KBK lean dairy } \\
\text { milk normal range of dry } \\
\text { milk } 1.19 \%-13.58 \% \text { and dry } \\
\text { ingredients without milk fat } \\
5.87 \%-9.78 \% \text {. } \\
\text { Kadar protein is } 5.40 \%- \\
5.78 \% \text {. Milk protein content } \\
\text { in this study is above the } \\
\text { minimum standard milk } \\
\text { codex is } 2.8 \% \text {. }\end{array}$ & $\begin{array}{l}\text { This treatment can } \\
\text { be applied to dairy } \\
\text { farms but has low } \\
\text { coarse fiber }\end{array}$ \\
\hline
\end{tabular}




\begin{tabular}{|l|l|l|l|}
\hline & & $\begin{array}{l}\text { Kadar highest milk fat } \\
\text { obtained in dairy cows given } \\
\text { the P3 ration (5.325\%) and } \\
\text { lowest in cows treated with } \\
\text { P0 }(3.8 \%)\end{array}$ \\
\hline $\begin{array}{l}\text { (Pasue dan Salah } \\
\text { 2019) }\end{array}$ & $\begin{array}{l}\text { Corn Straw }\left(10,60^{\mathrm{a}}, 11,15^{\mathrm{a}}, 8,57^{\mathrm{b}}\right. \\
+ \text { Trichoderma Viride } \\
\left.10,55^{\mathrm{a}}\right), \text { Selulosa }\left(32,96^{\mathrm{b}},\right. \\
\left.32,93^{\mathrm{b}}, 32,48^{\mathrm{b}}, 34,55^{\mathrm{a}}\right),\end{array}$ & $\begin{array}{l}\text { Treatment on P1, } \\
\text { P3 and P4 was not } \\
\text { Hemiselullosa }\left(22,59^{\mathrm{a}},\right. \\
\left.15,30^{\mathrm{b}}, 11,78^{\mathrm{c}}, 12,27^{\mathrm{c}}\right)\end{array}$ & $\begin{array}{l}\text { able lower } \\
\text { lignin, cellulose } \\
\text { and hemicellullose } \\
\text { levels. }\end{array}$ \\
\hline
\end{tabular}

The use of rice straw as feed is mainly done processing to increase the nutrient content and at the same time should be supported by concentrate supplements in improving the digestiability of rice straw. Crude protein content of rice straw $4.5 \%$, LK $1.0 \%$, extract material without nitrogen $42 \%$, ash $16.50 \%$, and BK $80 \%$ and low digestiility levels range from 30-40\% (Suningsih and Sadjadi 2020). That's because the rice straw cell wall has undergone advanced lignification. In addition, there is a complex bond between cellulose, hemicellulose and lignin into lignocellulose and lignohemicellulose which is very difficult to digest by rumen microbes (Suningsih et al. 2019). Successively the content of cellulose 33\% and hemicellulose $26 \%$ that can be used by ruminant livestock as a source of energy, but difficult to digest by microbes rumen (Suningsih and Sadjadi 2020). In addition, rice straw has fiber components (cellulose, hemicellulose, and lignin) and silica with crude protein content ranging from 3-5\% of dry materials, mineral content of calcium and phosphorus $0.41 \%$ and $0.29 \%$, whereas safe feeding for ruminant livestock is about $1.0 \% \mathrm{Ca}$ and $0.75 \%$ Posfor from dry rations.

The weakness of rice straw utilization is also found in coarse fibers because it contains silica in organic groups as much as $12-16 \%$. Silica is a crystal in the cell wall and fills the space between cells and is insoluble in rumen fluid, thus becoming an obstacle for rumen microbes and enzymes to digest rice straw (Yanuartono et al. 2019). Also, the factor inhibiting the digestibility is the presence of lignin content that can not be destroyed rumen microbes. Ruminant cattle such as cows, given $100 \%$ rice straw without a touch of technology will experience stunted growth (Sukaryani 2019). Because, the nutritional content in rice straw without processing is not able to meet the needs for basic living or for production. In addition, prolonged administration will lead to death. It is caused by crystallization of cellulose and hemicellulose which can inhibit the work of enzymes in digesting rice straw cell walls (Rhofita and lilik 2019; Rhofita 2016). Such low digestibility is due to the structure of the buffer tissue of plants that are old and undergo advanced lignification processes and consequently lignocellulose and lignohemicellulose are difficult to digest (Nahak et al. 2019; Jamaluddin, et al. 2019; Handayanta et al. 2013).

As a source of animal feed, rice straw is classified as low quality. Thus, livestock are only able to consume less than $3 \%$ of the body weight of cattle due to the slow rate of movement in the gastrointestinal tract (Partama et al. 2019). The speed of degradation greatly affects the mechanism of eating and the amount of consumption. If the rate of degradation is fast then the amount of consumption becomes increased, and vice versa, if the rate of degradation is slow then the consumption will be little. Urea ammonia rice straw must be 
supported by concentrates containing energy and easy to ferment, because the production of ammonia in rumen comes from urea faster after eating (Kusumaningrum et al. 2018; Ilham et al. 2018). So that low quality feed, such as rice straw is able to provide enough energy in a relatively short time for maximum microbial mass production purposes. Each balance of urea ammonia rice straw and concentrates in the ration will directly affect the efficiency level of microbial protein synthesis (Yanti et al. 2017). Formulation of rations is expected to synchronize energy needs with proteins for the growth and formation of microbial rumen proteins followed by increased concentrate content and increased $\mathrm{pH}$ and total VFA of rumen fluid.

\section{Feed Materials From Plantation Follow-up}

Feed material from plantation follow-up is a potential in the utilization of animal feed sources that are increasingly reduced due to land used for housing and the tendency of farmers to plant land with agricultural crops that can be directly useful for human needs. Therefore, the use of agricultural waste as an alternative feed is a solution to the shortage of ruminant animal feed. Application of feed biotechnology in testing the nutritional quality of agricultural follow-ups presented in Table 3.

Table 3. Application of feed biotechnology in plantation follow-up results

\begin{tabular}{|c|c|c|c|}
\hline Research & Waste & Research Results & Deficiency \\
\hline Sinurat (2003) & Palm oil & $\begin{array}{l}\text { The nutritional content } \\
\text { of dry palm oil is } \\
11.9 \% \text { crude protein } \\
\text { and } 29.76 \% \text { coarse } \\
\text { fiber. }\end{array}$ & - \\
\hline Hidayat et al. (2007) & $\begin{array}{l}\text { Palm oil + Aspergillus } \\
\text { niger }\end{array}$ & $\begin{array}{l}\text { Coarse protein } 22,07 \% \text {, } \\
\text { coarse fiber } 18,6 \% \text {, } \\
\text { energi } 1717 \mathrm{kkal} / \mathrm{kg}, \\
\mathrm{Ca} 1,24 \% \text { dan } \mathrm{P} \\
0,65 \% .\end{array}$ & - \\
\hline Lubis et al. (2016) & $\begin{array}{l}\text { Palm sludge }+ \\
\text { Aspergillus niger } \\
\text { (Kampung Chicken) }\end{array}$ & $\begin{array}{l}\text { R0 7,34 } \pm 1,01, \mathrm{R} 1 \\
9,20 \pm 0,83, \mathrm{R} 29,25 \pm \\
1,28, \mathrm{R} 39,41 \pm 1,33 \\
\text { and R4 } 8,77 \pm 1,36\end{array}$ & $\begin{array}{l}\text { Treatment given fresh } \\
\text { palm oil sludge } \\
\text { shows a fairly good } \\
\text { result compared to } \\
\text { the treatment given } \\
\text { fermented palm } \\
\text { sludge products. }\end{array}$ \\
\hline $\begin{array}{l}\text { Nurhayu and Ishak } \\
(2015)\end{array}$ & $\begin{array}{l}\text { Palm Oil and } \\
\text { Derivatives of Results }\end{array}$ & $\begin{array}{l}\text { Palm leaves, BK } \\
46,18 \%, \text { Abu } 13,40 \%, \\
\text { PK 14,12\%, SK } \\
21,52 \%, \text { LK } 4,37 \%, \\
\text { BETN 46,59\%, Ca } \\
0.84 \% \text {, dan P } 0,17 \% \text {. } \\
\text { Pelepah, BK } 26,07 \%, \\
\text { Abu 5,10\%, PK 3,07\%, } \\
\text { SK 50,94\%, LK } \\
1,07 \%, \text { BETN 39,82\%, } \\
\text { Ca 0,96\%, dan P } \\
0,08 \% \text {. }\end{array}$ & $\begin{array}{l}\text { coarse fibers are quite } \\
\text { high. Furthermore, if } \\
\text { palm oil waste } \\
\text { products are used for } \\
\text { livestock can cause a } \\
\text { shortage of nutrients } \\
\text { so as to decrease } \\
\text { productivity so that } \\
\text { before being utilized } \\
\text { first treatment is done } \\
\text { to improve the quality } \\
\text { and digestibility }\end{array}$ \\
\hline
\end{tabular}




\begin{tabular}{|c|c|c|c|}
\hline & & $\begin{array}{l}\text { Palm sludge BK } \\
24,08 \%, \text { Abu 14,40\%, } \\
\text { PK 14,58\%, SK 35,8\%, } \\
\text { LK 14,78\%, BETN } \\
\text { 16,36\%, Ca 1,08\%, dan } \\
\text { P 0,25\%. } \\
\text { Bungkil BK 91,83\%, } \\
\text { Abu 4,14\%, PK } \\
\text { 16,33\%, SK 36,68\%, } \\
\text { LK 6,49\%, BETN } \\
\text { 28,19\%, Ca 0,56\%, dan } \\
\text { P 0,84\%. } \\
\text { Squeezed Fiber BK } \\
\text { 93,11\%, Abu 5,90\%, } \\
\text { PK 6,20\%, SK 48,10\%, } \\
\text { dan LK 3,22\%. } \\
\text { Tandan kosong BK } \\
\text { 92,10\%, Abu 7,89\%, } \\
\text { PK 3,70\%, SK 47,93\%, } \\
\text { LK 4,70\%, Ca 0,24\%, } \\
\text { dan P 0,04\%. }\end{array}$ & $\begin{array}{l}\text { (Indraningsih et al. } \\
\text { 2006). }\end{array}$ \\
\hline Sinurat (2005) & $\begin{array}{l}\text { Cocoa skin }+ \\
\text { Aspergilus niger }\end{array}$ & $\begin{array}{l}\text { Coarse protein } 9,15 \% \text {, } \\
\text { lemak } 1,25 \% \text { serat } \\
\text { kasar } 32,7 \% \text { dan TDN } \\
50,3 \% \text {. }\end{array}$ & $\begin{array}{l}\text { Contains } \\
\text { antinutrients, such as } \\
\text { alkaloids and tannins }\end{array}$ \\
\hline Sutardi (1991) & $\begin{array}{l}\text { Cocoa skin }+ \\
\text { Aspergilus niger }\end{array}$ & $\begin{array}{l}12,6 \% \text { abu, } 8,9 \% \\
\text { protein kasar, } 0,90 \% \\
\text { lemak kasar, } 34,50 \% \\
\text { serat kasar, dan energi } \\
\text { metabolisnya } 1746 \\
\text { kka/kg bahan kering. }\end{array}$ & $\begin{array}{l}\text { Contains } \\
\text { antinutrients, such as } \\
\text { alkaloids and tannins }\end{array}$ \\
\hline $\begin{array}{lll}\text { Zaenuddin } & \text { et } & a l . \\
(1995) & & \end{array}$ & Fermented coffee skin & $\begin{array}{l}\text { Protein kasar } 10,4 \% \text {, } \\
\text { serat kasar } 17,2 \% \text { dan } \\
\text { energi metabolismenya } \\
\text { sebesar } 14,43 \mathrm{MJ} / \mathrm{kg}\end{array}$ & $\begin{array}{l}\text { Contains antinutrient } \\
\text { compounds in the } \\
\text { form of caffeine } 1.3 \% \\
\text { and tannins } 8.5 \% \text {. }\end{array}$ \\
\hline Wiguna, (2007) & Fermented coffee skin & $\begin{array}{l}95.22 \% \text { dry material; } \\
10.47 \% \text { coarse protein; } \\
0.26 \% \text { fat; } 32.26 \% \\
\text { coarse fiber; and } \\
\text { contains energy }(\mathrm{GE}) \\
\text { of } 4140 \mathrm{kcal} / \mathrm{kg} \text {. }\end{array}$ & $\begin{array}{l}\text { Contains antinutrient } \\
\text { compounds in the } \\
\text { form of caffeine } 1.3 \% \\
\text { and tannins } 8.5 \% \text {. }\end{array}$ \\
\hline Mastika (2011) & Ammonia coffee skin & $\begin{array}{l}\text { The process of } \\
\text { ammoniation, it turns } \\
\text { out that the nutritional } \\
\text { content of coffee skin } \\
\text { increases, namely } \\
\text { coarse protein to } \\
17.88 \% \text {; digestiability } \\
\text { of dry materials } \\
\text { increased from } 40 \% \text { to } \\
50 \% \text {. }\end{array}$ & $\begin{array}{l}\text { Contains antinutrient } \\
\text { compounds in the } \\
\text { form of caffeine } 1.3 \% \\
\text { and tannins } 8.5 \% \text {. }\end{array}$ \\
\hline
\end{tabular}

The higher production and area of oil palm plantations from year to year will also increase the volume of waste, both in the form of solid waste and liquid waste. Palm oil waste 
is the remnants of oil palm crops that are not included in the main products or are the result of a follow-up to the palm oil processing process (Pranata and Arico 2019). Barriers to the utilization of pelepah as animal feed is low crude protein around $2.11 \%$ and high content of coarse fiber reached 46.75\% (Murni et al., 2008). Efryantoni (2012), stated that the level of digestitude of dry oil palm oil only reached $45 \%$. To overcome the weakness of the use of pelepah and palm leaves as animal feed is carried out maximum inclusion in the form of processing through feed technology, one of which is by fermentation. According to Gunawan and Talib (2014), pelepah and palm oil leaves can be used as fodder for grass replacement cattle as a source of forage, because it has a high enough coarse fiber (SK) with high lignin levels, namely $17.4 \%$ and $27.6 \%$ ).

Carbohydrate fraction (BETN) in cocoa shell is easy to digest, but the digestibility of coarse fiber is low due to high levels of NDF (Neutral Detergent Fibre), namely 66.30\%, ADF (Acid Detergent Fibre) 65.10\%, lignin 28.0\%, and silica $0.17 \%$. As a feed ingredient cocoa fruit skin has a drawback that contains antinutrient, such as alkaloids and tannins, so as to decrease the utilization of other nutrients. In addition, the structure of the cell wall is very hard because it contains high coarse fibers, causing its level of digestiility to be low. Low quality can be addressed through processing, including physical (enumeration / milling), chemically such as ammonia, and biologically (fermentation).

Alternative provision of cheap and competitive feed can be through the utilization of waste both agricultural and industrial products. However, coffee skin has a moisture content $(75-80 \%)$ cause easily damaged in a fast time. Efforts in solving the problem One of them is silage technology, which is fermentation technology in increasing nutrient levels, especially protein and energy. In addition, this technology can also maintain the freshness of feed ingredients with dry ingredients content of 30-35\% (Simanihuruk et al. 2010). Through ammoniation the structure of coffee skin cell walls becomes dense and dusty and easier to consume by livestock. The utilization of coffee skin as a concentrate feed campuan can increase the added value of farming through ammonia technology to be a new breakthrough for the world of waste utilization. Even as a medium of income farmers or farmers through feeding supplementation nutrition is cheap but has good quality.

\section{CONCLUSION}

The application of feed biotechnology essentially helps improve the quality of products as well as knowledge about feed biotechnology. Thus, it is expected to have an impact to increase the production of ruminant livestock. The application of biotechnology rice straw feed as feed aims to increase the nutritional content but should also be supported by concentrate supplements in improving the digestiability of rice straw. Furthermore, the follow-up of oil palm plantations and their derivatives such as pelepah and palm oil leaves can be used as animal feed but have high coarse fiber with high lignin levels. So the use of technologies such as ammonia, as well as biologically (fermentation) needs to be applied to improve the quality and digestibility of livestock. 


\section{REFERENCES}

Handayanta, Eka, Ristanto Utomo, and Mohamad Soejono. 2013. "Pengaruh Amoniasi Urea dan Varietas terhadap Kadar Protein Kasar Jerami Padi." Buletin Peternakan 14(1):15-18.

Hanum, Zuraida, and Yunasri Usman. 2011. "Analisis Proksimat Amoniasi Jerami Padi Dengan Penambahan Isi Rumen.” Jurnal Agripet 11(1):39-44.

Haryo, Mercky, Amzul Rifin, and Bunasor Sanim. 2017. "Factors Affecting Profitability on Animal Feed Companies in Indonesia." Agro Ekonomi 28(2):289. doi: 10.22146/jae.26034.

Ilham, Fahrul, Muhammad Sayuti, and Tri Ananda Erwin Nugroho. 2018. "Peningkatan Kualitas Jerami Padi Sebagai Pakan Sapi Potong Melalui Amoniasi Mengunakan Urea Di Desa Timbuolo Tengah Provinsi Gorontalo." Jurnal Pengabdian Kepada Masyarakat 24(2):717-22. doi: 10.24114/jpkm.v24i2.10735.

Iqbal, Zul, Yunasri Usman, and Sitti Wajizah. 2016. "Evaluasi Kualitas Jerami Padi Fermentasi Dengan Tingkat Penggunaan EM-4 Yang Berbeda." Jurnal Ilmiah Mahasiswa Pertanian 1(1):655-64. doi: 10.17969/jimfp.v1i1.1135.

Jamaluddin, Darmawan, Nurhaeda Nurhaeda, and Rasbawati Rasbawati. 2019. "Analisis Kandungan Protein Kasar dan Serat Kasar Silase Pakan Komplit Berbahan Dasar Kombinasi Jerami Padi dan Daun Lamtoro Sebagai Pakan Ternak Ruminansia." bionature 19(2):105-11. doi: 10.35580/bionature.v19i2.9727.

Kusumaningrum, Crhisterra Ellen, Irawan Sugoro, and Pingkan Aditiawati. 2018. "Pengaruh Silase Sinambung Jerami Jagung Terhadap Fermentasi Dalam Cairan Rumen Secara In Vitro." Jurnal Ilmu Ternak Universitas Padjadjaran 18(1):26-33. doi: 10.24198/jit.v18i1.14460.

Lubis, F. N. L., S. Sandi, and J. W. Wardana. 2016. "Pengaruh Lumpur Sawit Fermentasi dalam Ransum Terhadap Performa Ayam Kampung Periode Grower." Jurnal Peternakan Sriwijaya 4(2). doi: 10.33230/JPS.4.2.2015.2806.

Lukiwati, Dwi Retno, Karno -, and Budi Adi Kristanto. 2016. "Peningkatan Produksi Jagung Manis dan Jerami dalam Sistem Integrasi Tanaman Pangan dan Peternakan Sapi Brangus." Jurnal Ilmu Ternak Universitas Padjadjaran 16(2):89-94. doi: 10.24198/jit.v16i2.11581.

Mardalena, Mardalena, S. Syarif, and H. Ediyanto. 2018. "Efek Subtitusi Jerami Jagung dengan Pelepah Sawit Fermentasi terhadap Kualitas Susu Sapi Perah." Jurnal Sain Peternakan Indonesia 13(4):351-56. doi: 10.31186/jspi.id.13.4.351-356.

Mayulu, H., and Suhardi Suhardi. 2016. "Potency and Carrying Capacity of Rice Straw for Beef Cattle Feeding in East Kalimantan." Jurnal Ilmu Dan Teknologi Peternakan 4(3):119-29.

Muhtarudin, Muhtarudin, Liman Liman, Indra Cahya Ardi, Ines Pangestika, Gusti Aji Wijian, Eli Susanti, and Kusuma Adhianto. 2018. "The Effect of Rations Based on Palm Oil By-Products on Rumen Parameters and Digestibility in Ongole Cattle." Pakistan Journal of Nutrition 17(12):622-26. doi: 10.3923/pjn.2018.622.626.

Nahak, Oktovianus R., Maria Magdalena Kolo, and Hilarius Y. Sikone. 2019. "Aplikasi Teknologi Fermentasi Jerami Padi Sebagai Sumber Pakan Alternatif Ternak Sapi Bali Untuk Mengatasi Kekurangan Pakan Di Kelompok Tani Nek'to Noapala Desa Kiuola Kecamatan Noemuti Kabupaten TTU." Bakti Cendana 2(1):23-29. doi: 10.32938/bc.v2i1.96.

Nugroho, Alden Imawan, Muhtarudin, and Yusuf Widodo. 2016. "Pengaruh Penambahan Jenis Bahan Pakan Sumber Protein Pada Ransum Berbasis Hijauan Kelapa Sawit 
Terhadap Kecernaan Bahan Kering Dan Bahan Organik Pada Kelinci Lokal Jantan.” Jurnal Ilmiah Peternakan Terpadu 4(3). Doi: 10.23960/Jipt.V4i3.P\%P.

Nurhayu, A., and A. B. L. Ishak. 2015. "Pelepah Dan Daun Sawit Sebagai Pakan Substitusi Hijauan Pada Pakan Ternak Sapi Potong Di Kabupaten Luwu Timur Sulawesi Selatan.” Balai Pengkajian Teknologi Pertanian Sulawesi Selatan 108-15.

Partama, Partama I. B., I. G. N. G. Bidura, and D. P. M. A. Candrawati. 2019. "Optimalisasi Pemanfaatan Jerami Padi Sebagai Pakan Dasar Sapi Bali Penggemukan Melalui Perlakuan Amoniasi Dan Biofermentasi Dengan Mikroba." Majalah Ilmiah Peternakan 22(3):132-39. doi: 10.24843/MIP.2019.v22.i03.p07.

Pasue, Ismail Ismail, and E. Salah. 2019. “Analisis Lignin, Selulosa Dan Hemi Selulosa Jerami Jagung Hasil Di Fermentasi Trichoderma Viride Dengan Masa Inkubasi Yang Berbeda." Jambura Journal of Animal Science 1(2):62-67. doi: 10.35900/jjas.v1i2.2607.

Pranata, Ricky Hadi, and Zulfan Arico. 2019. "Pemanfaatan Limbah Kebun Pelepah Kelapa Sawit (Elaeis guinensis Jacq) Sebagai Alternatif Pakan Ternak Bernilai Gizi Tinggi." Jurnal Biologica Samudra 1(1):17-24.

Rhofita, Erry Ika. 2016. "Kajian Pemanfaatan Limbah Jerami Padi Di Bagian Hulu.” Al-Ard: Jurnal Teknik Lingkungan 1(2):74-79. doi: 10.29080/alard.v1i2.118.

Rhofita, Erry Ika, and Liliek Chana Aw. 2019. "Pemanfaatan Limbah Jerami Padi Di Desa Garon Kecamatan Balerejo, Kabupaten Madiun.” Jurnal Inovasi Hasil Pengabdian Masyarakat (JIPEMAS) 2(2):120-31. doi: 10.33474/jipemas.v2i2.2915.

Saputro, R. a. T. W., N. Ngadiyono, L. M. Yusiati, and I. G. S. Budisatria. 2015. "Kecernaan In Vitro Jerami Padi Fermentasi Dengan Menggunakan Berbagai Level Inokulum Aspergillus Niger Dan Lactobacillus Plantarum." Jurnal Pengembangan Penyuluhan Pertanian 11(22):25-35. doi: 10.36626/jppp.v11i22.144.

Setiarto, R. Haryo Bimo. 2016. "Prospek Dan Potensi Pemanfaatan Lignoselulosa Jerami Padi Menjadi Kompos, Silase Dan Biogas Melalui Fermentasi Mikroba." Jurnal Selulosa 3(02). doi: 10.25269/jsel.v3i02.44.

Siahaan, Andysah Putera Utama and Rusiadi. 2018. "Effect of Palm Oil and Cattle Wastes Combination on Growth and Production of Sweet Corn." International Journal of Civil Engineering and Technology 9(10):1498-1507. doi: 10.31227/osf.io/qnxjr.

Sukaryani, Sri. 2019. "Kajian Kandungan Lignin Dan Selulosa Jerami Padi Fermentasi." Agrisaintifika: Jurnal Ilmu-Ilmu Pertanian 2(2):160-65. doi: 10.32585/ags.v2i2.267.

Suningsih, N., W. Ibrahim, O. Liandris, and R. Yulianti. 2019. "Kualitas Fisik dan Nutrisi Jerami Padi Fermentasi pada Berbagai Penambahan Starter.” Jurnal Sain Peternakan Indonesia 14(2):191-200. doi: 10.31186/jspi.id.14.2.191-200.

Suningsih, N., and Sadjadi Sadjadi. 2020. "Efek Penambahan Tepung Daun Sirsak (Annona Muricata L) dalam Ransum Berbasis Jerami Padi Fermentasi terhadap Kecernaan Bahan Kering dan Bahan Organik Secara In Vitro." Jurnal Sain Peternakan Indonesia 15(2):173-79. doi: 10.31186/jspi.id.15.2.173-179.

Suningsih, Nining, and Sadjadi Sadjadi. 2020. "Nilai PH, VFA, Dan NH3 Ransum Berbasis Jerami Padi Fermentasi Yang Diberi Penambahan Tepung Daun Sirsak (Annona Muricata) Secara In Vitro." Journal of Livestock and Animal Health 3(2):32-38. doi: 10.32530/jlah.v3i2.274.

Syapura, Syapura, Muhamad Bata, and Wardhana Surya Pratama. 2013. "Peningkatan Kualitas Jerami Padi Dan Pengaruhnya Terhadap Kecernaan Nutrien Dan Produk Fermentasi Rumen Kerbau Dengan Feces Sebagai Sumber Inokulum.” Jurnal Agripet 13(2):59-67. doi: 10.17969/agripet.v13i2.822.

Tohiran, Kamil A., Frisco Nobilly, Raja Zulkifli, Adham Ashton-Butt, and Badrul Azhar. 2019. "Cattle-Grazing in Oil Palm Plantations Sustainably Controls Understory 
Vegetation." Agriculture, Ecosystems \& Environment 278:54-60. doi: 10.1016/j.agee.2019.03.021.

Tohiran, Kamil A., Frisco Nobilly, Raja Zulkifli, Thomas Maxwell, Ramle Moslim, and Badrul Azhar. 2017. "Targeted Cattle Grazing as an Alternative to Herbicides for Controlling Weeds in Bird-Friendly Oil Palm Plantations."Agronomy for Sustainable Development 37(6):62. doi: 10.1007/s13593-017-0471-5.

Yanti, Y., Y. Kawamoto, T. Miyagi, B. Rahmi, Surahmanto Surahmanto, and A. Purnomoadi. 2017. "Pengaruh Perbedaan Mikroorganisme Dan Suhu Pada Kandungan Serat Jerami Padi Fermentasi." Sains Peternakan: Jurnal Penelitian Ilmu Peternakan 12(2):11421. doi: 10.20961/sainspet.v12i2.4794.

Yanuartono, Yanuartono, S. Indarjulianto, H. Purnamaningsih, A. Nururrozi, and S. Raharjo. 2019. "Fermentasi: Metode untuk Meningkatkan Nilai Nutrisi Jerami Padi." Jurnal Sain Peternakan Indonesia 14(1):49-60. doi: 10.31186/jspi.id.14.1.49-60. 